\title{
Kols of Shankargarh Silica Mines
}

\author{
Ashutosh Mishra ${ }^{1}$ \\ Research Scholar, Geography Department, University of Allahabad, India
}

\begin{abstract}
The Shankargarh block of Allahabad district of Uttar Pradesh, India, is well known for its high quality silica sand, and large scale surface mining is being done here. Most of the mining workers belong to a forest-dwelling community- Kol. Although, their life was never easy, they were fulfilling their needs by selling forest produces. As forest was occupied by mines, Kols became unsheltered and resourceless. They started working as silica sand mining labours to earn their livelihood. These men are mostly underpaid, extremely poor and homeless. They are deprived by all basic amenities and services and are struggling for their survival by more than seventy years.
\end{abstract}

Key Words: Forest dwellers; Shankargarh sand; ferrous contamination; social entropy

\section{INTRODUCTION}

Eight thousand years ago, when humans played only bit parts in the world ecosystem, trees covered two-fifths of the land. Since then, humans have grown in number while thinning and shaving the forests. Forests really matter for the humankind and the whole biota. They protect watersheds and generate clean drinking water; they remove carbon dioxide from the air and thus help maintain the climate. Beside all these, they provide the life support system of thousands of forest-dwelling and tribe communities.

The exploitation of mineral resources in the forest realm is a key factor in economic growth and development, but one that can have serious negative environmental and socioeconomic impacts. Almost all of India's minerals are in the same regions that hold its greenest forests and most abundant river systems. These lands are also largely inhabited by India's poorest and most marginalized people - the scheduled tribes and scheduled castes who depend on the very same forests and watersheds for their survival. Forest degradation due to mining in addition to other development projects has significantly depleted the ecosystem, rendering the forest dependant population socially and economically more vulnerable.

Present paper discusses the socio-economic state of Kols, residing in northern foothill region of the Vindhyan mountain in south-west part of Allahabad district. Though the Kols are anthropologically tribal (Majumdar, 1941; Soni, 2013), they are recognized as a Scheduled Caste in state of Uttar Pradesh. Not only has this deprived them of their traditional source of living-the forest, it has largely left them dependant and landless, languishing in silica quarries and sand mines. Landless and dismayed by the rocky terrain that makes cultivation difficult, the Kols settle down close to silica mines, crushing stones for much of the day and bearing a nomadic existence.

The discussion is based on the survey done in Shankargarh block- a part of Trans-Yamuna region of Allahabad district- where most of the Kol population lives. Shankargarh is situated in the catchment's area of river Tons. The area is rocky and has been gifted with high quality silica sand- an important source of glass sand, containing 98 percent $\mathrm{SiO}_{2}$ and a very low $\mathrm{Fe}_{2} \mathrm{O}_{3}$. The geological formation of the area is of the Vindhya sandstones. Whenever the cementing material of these sandstones has been leached out, they give rise to a very fine quality sand, popularly known as Shankargarh sand.

The King of Shankargarh has mining rights over 46 villages (covering an area of 150 sq. kms.) in perpetuity and gives the rights to contractors who in turn hire local labourers to extract minerals, at extremely exploitative rates.

\section{SOCIO-ECONOMIC STATE OF THE KOLS}

Historically Kol was a forest-dwelling community, having their own tradition, rights and rituals. Forest was their home, and was able to provide all the means of their livelihood. Employment and land was never their concern as the whole forest and its produces were of them. But about seven decades ago, when mining operations started in the region, they became destitute and homeless. They started working as bonded labourers in stone quarries. Given that stone is a crop that can be harvested throughout the year-barring days of heavy rainfall- whole families engage in breaking silica rocks for livelihood and consequently breathing silica dust.

${ }^{1}$ Corresponding Author:ashutoshkmisra@gmail.com 
Kols are in initial phase of social development. Their struggle to make them fit to survive in contemporary social settings is going on. They are deprived in all means. Literacy level is very poor. Most of them are homeless and landless. Large number of Kol population have short life span as they die due to Tuberculosis due to inhaling silica. After many laudable efforts by SHGs and NGOs to bring them in mainstream, development is still awaited in their lives. The gap between them and the rest of the social groups is large and becoming larger every day.

To measure the real socio-economic state of Kols, and that expanding gap between them and rest of the world, the study proposes a $\mathbf{5 S}$ model. This model is based on 5 basic services- Home, Land, Health, Education and Employment (Fig. 1). The balance between these basic elements determines the social sustainability and assures holistic development of any society.

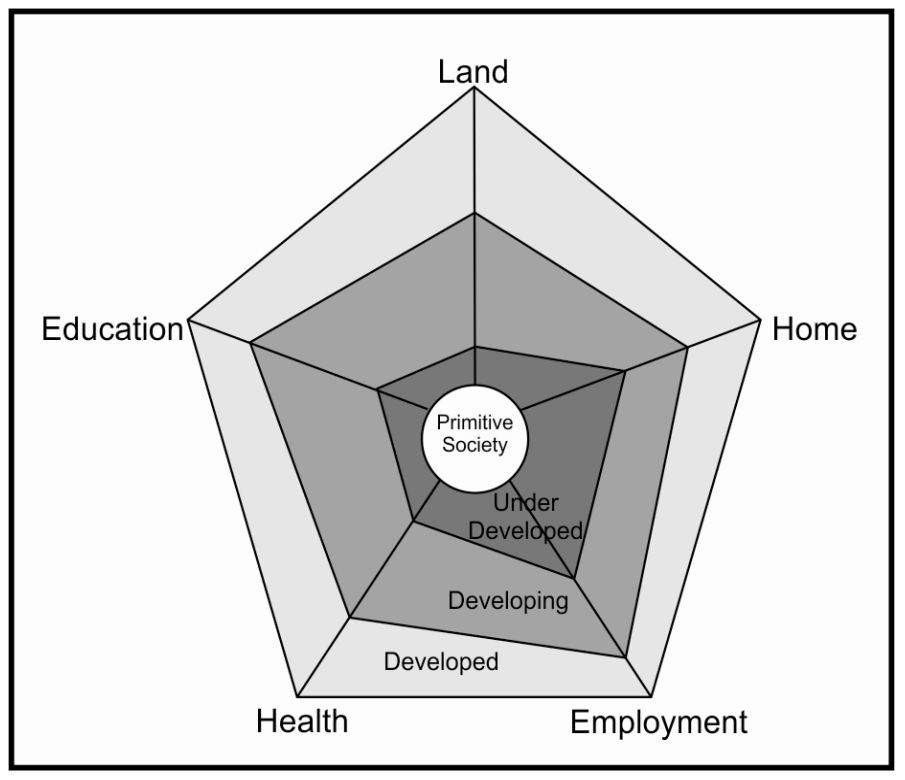

Fig.1. Model of Holistic Social Development

To collect respondents' feedback, $100 \mathrm{Kol}$ people from 16 villages (Fig. 2), where intensive mining activities are in operation, were interviewed with 20 questions pertaining to the availability of Health services, Education, Employment, Home and Land. Their responses were obtained in 'Yes' or 'No' (Table 1). Another survey, with same questions among 100 non-Kol people of the same area, was also conducted to deduce the actual developmental lapses.

Table 1. Queried information regarding five basic services

\begin{tabular}{|c|c|c|c|c|}
\hline $\begin{array}{c}\text { Health } \\
\text { service }\end{array}$ & Education & Employment & Home & Land \\
\hline $\begin{array}{c}\text { Government } \\
\text { Health } \\
\begin{array}{c}\text { Facility } \\
\text { Availed }\end{array}\end{array}$ & Literate & Employed & Permanent Home & Own Land \\
\hline $\begin{array}{c}\text { Potable Water } \\
\text { Available }\end{array}$ & $\begin{array}{c}\text { Education up to } \\
\text { High School }\end{array}$ & Employed as labourers & Pucca Home & Cultivable Land \\
\hline $\begin{array}{c}\text { Suffering } \\
\text { from Chronic } \\
\text { Disease }\end{array}$ & Graduate & $\begin{array}{c}\text { Underpaid Labourers } \\
\text { (Below MGNREGA Rates) }\end{array}$ & $\begin{array}{c}\text { Home With More } \\
\text { Than One Room }\end{array}$ & $\begin{array}{c}\text { Cultivable Land } \\
\text { on Lease }\end{array}$ \\
\hline $\begin{array}{c}\text { Aware About } \\
\text { Family } \\
\text { Planning }\end{array}$ & $\begin{array}{c}\text { Passed Professional } \\
\text { Degree }\end{array}$ & Own Business & $\begin{array}{c}\text { Home With Toilet } \\
\text { Facility }\end{array}$ & $\begin{array}{c}\text { Mining Land on } \\
\text { Lease }\end{array}$ \\
\hline
\end{tabular}


American Research Journal of Humanities and Social Sciences, Volume 1, Issue1, Feb-2015 ISSN 2378-7031

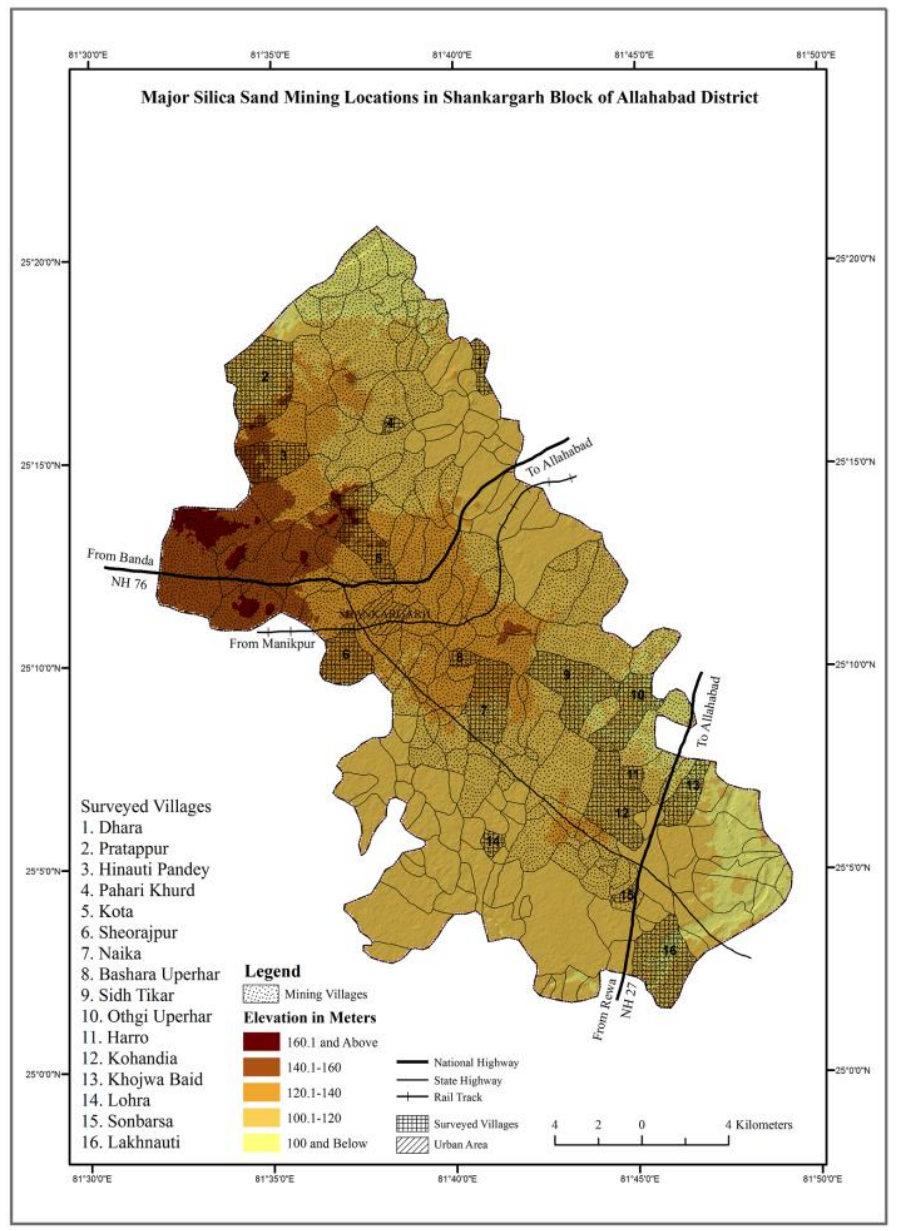

Fig.2. Surveyed villages

On the basis of service-wise averaged scores obtained from respondent's feedback, the state of development in both the communities- non-Kol and Kol, has been presented in figure 3.

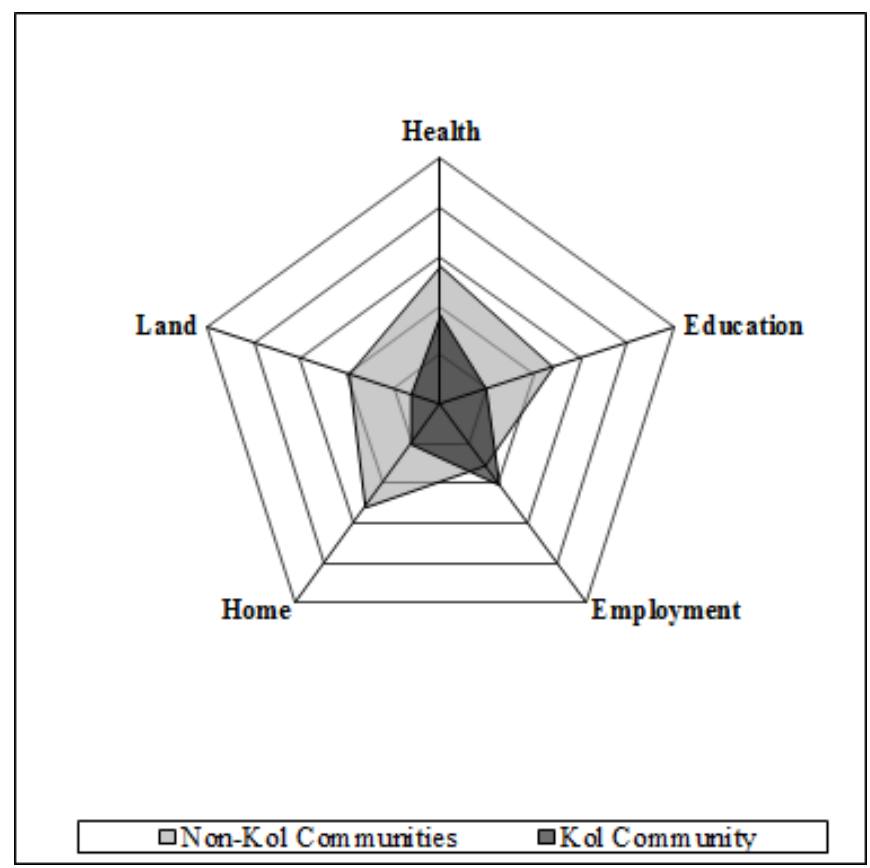

Fig.3. State of development in Kol and Non-Kol communities 


\section{American Research Journal of Humanities and Social Sciences, Volume 1, Issue1, Feb-2015 ISSN 2378-7031}

It is evident that the region is socially underdeveloped and the Kols are occupying the lowest rung. They are mostly homeless and have very limited accesses to land resources. The condition of health and education is very poor. Although the employment rate in Kols are higher than other residing communities of the region but most of them are working as underpaid silica sand quarrying labourers. Childs too, help their parents in earning every day's food by accompanying them in stone breaking (Fig. 4).

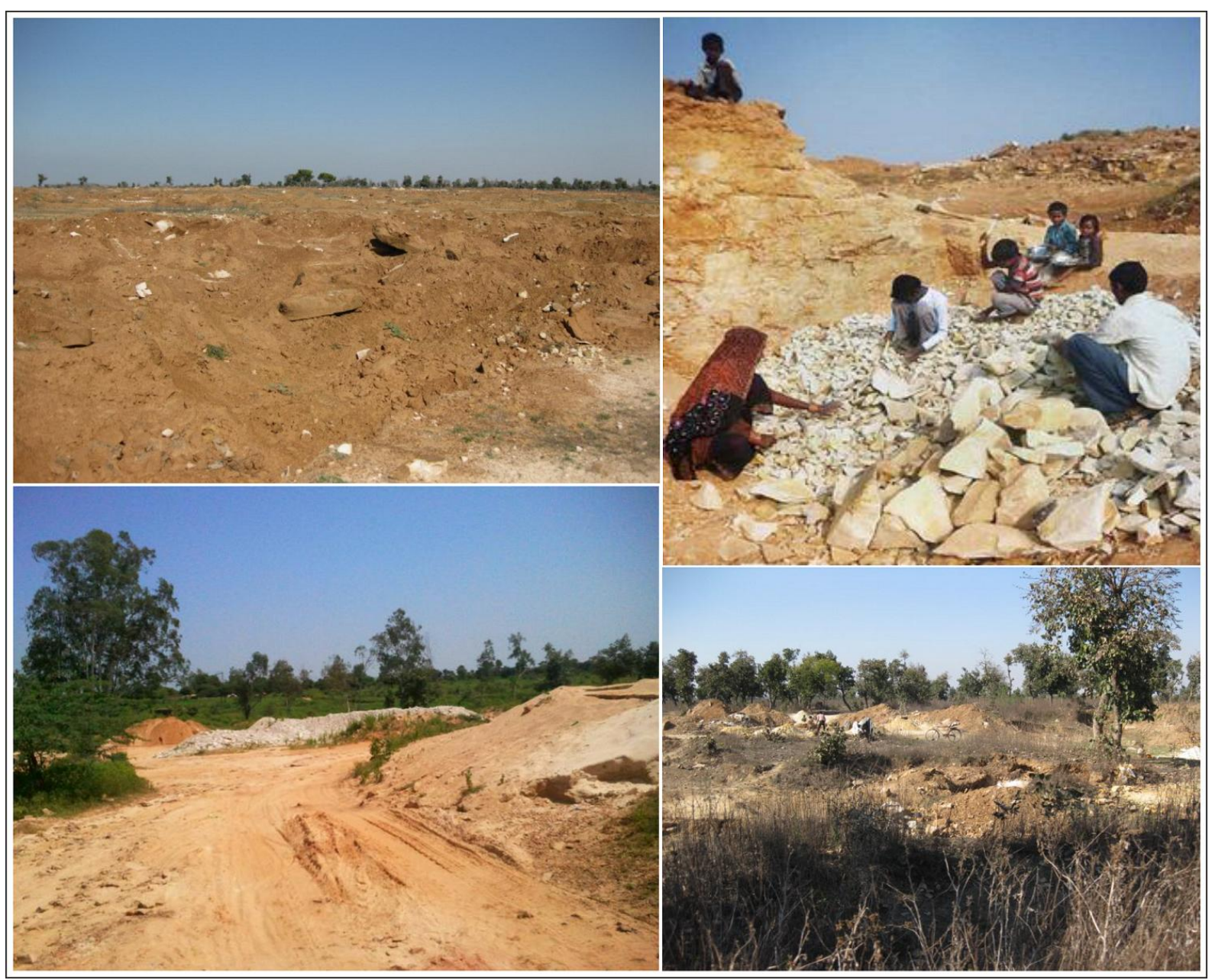

Fig.4. Mining sites at Sheorajpur village

At most of the mining sites, where these men break stones the whole day, there is no facility of medicinal first aid. Over the years, a large number have contracted lung diseases like silicosis and tuberculosis. Some have lost limbs or sustained crippling injuries during the blasting of the rocks. The water bodies of the area, which are the main source of water for most of these people, are being highly polluted due to silica mud and the ferrous contamination. These waterbodies serve as favourable breading places of Anopheles, and Kols resourcelessness makes them highly vulnerable to the maleria. This area own, records almost half of the total maleria cases in the district each year. The silica sand, heaped near cultivable land changes soil properties and due to sand refining works in extensive open areas near crop fields, the land is losing its fertility.

The agricultural land in the area is limited. Kols have the least share and that small share too is becoming barren. This process of gradual desertification of their lands will further push their livlihood towards labourship.

In such a condition any society, seeking its developmental threads, cannot take off when its wings are pierced by usurers and mining mafia's. Their lives are still the same as the great Indian poet Suryakant Tripathi Nirala had seen seven decades ago through his poem- "Todati Patthar". 


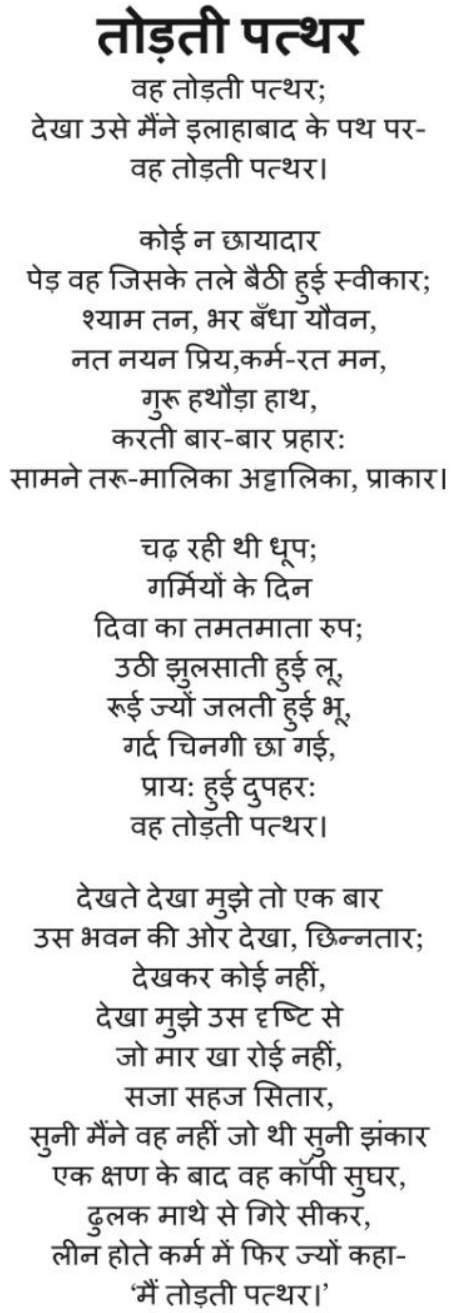

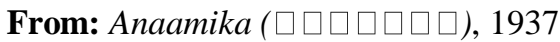

Time changed, but not Kols life. That hammer of Nirala`s poem is still in their hands, with the ribbon of poverty, hunger and malnutrition. No development can descend in their lives without removal of bondage labour system, strict regulation on mining activities and extensive and targeted poverty and illiteracy alleviation programmes. The five basic development pillars- education, health, land, home and employment are to be strengthened to elevate their social entropy and economic state.

\section{CONCLUSION}

For the forest-dwelling communities like Kols, the difficulty lies in the implementation of the Forests Rights Act- 2006. Under it, other forest-dwelling communities who are not Scheduled Tribes will have to provide proof of their presence in the forest for 75 years. Those recognised as tribal are free from this burden. The challenging question is: how can they produce proof of 75 years of residence when they have no residential rights and live like nomads? Due to this identity crisis, Kols have no rights for rehabilitation and compensation against removal of their home- the forests. Destruction of their life support system for mining and other activities leave them unsheltered and defenceless, and thus, in earning their meal they fall in the vicious trap of land owners, usurers and mining mafias. In protecting their culture and providing them basic amenities for a sound social and economic development targeted government efforts are the need of the hour so that development can descend in their lives in real sense.

\section{REFERENCES}

[1] Majumdar, D.N. (1944). The Fortunes of Primitive Tribes, Census Operations, United Provinces.

[2] Soni A. (2013). The Unquiet Tribal Scene of Uttar Pradesh. Ecological Democracy, 1(3), retrieved from http://www.ecologicaldemocracy.net/tree.php?action=view\&id=11, on December 12, 2014. 